\title{
DESKRIPSI KANDUNGAN BAKTERI Coliform PADA ES DAWET YANG DIJUAL DI KECAMATAN SOKARAJA TAHUN 2015
}

\author{
Kondang Bayu Prakarsa'), Dwi Bayu Karti Utami ${ }^{2)}$, Zaeni Budiono ${ }^{3)}$ \\ Jurusan Kesehatan Lingkungan, Politeknik Kesehatan Kemenkes Semarang, \\ Jl. Raya Baturaden KM 12 Purwokerto, Indonesia
}

\begin{abstract}
Abstrak
Es dawet merupakan salah satu minuman dengan bahan baku air sehingga sangat rawan terkontaminasi oleh mikroorganisme seperti jamur, kapang dan khamir. Salah satu bakteri yang relatif tahan hidup di air adalah bakteri Coliform.Biasanya dalam penjualan tidak memperhatikan 6 prinsip sanitasi.Tujuan umum penelitian ini adalah mengukur jumlah kandungan bakteri Coliform pada es dawet yang dijual oleh masing-masing penjual di Kecamatan Sokaraja Tahun 2015. Tujuan penelitian adalah menganalisis bakteri Coliform dalam es dawet dan mendeskripsikan sanitasi penjualan es dawet di Kecamatan Sokaraja.Penelitian ini merupakan penelitian deskriptif untuk memperoleh gambaran tentang kualitas es dawet dan sanitasi penjualan es dawet yang di jual di kecamatan Sokaraja.Hasil pemeriksaan laboratorium pada 5 pedagang es dawet menunjukan bahwa semua sampel melebihi batas maksimum cemaran mikroba yang telah ditentukan oleh Badan Pengawas Obat dan Makanan RI No.HK 00.06.1.52.4011 tentang penetapan batas maksimum cemaran mikroba dan kimia adalah < 3/ml. Disimpulkan bahwa jumlah bakteri Coliform pada es dawet yang dijual pada 5 pedagang es dawet di Kecamatan Sokaraja tidak ada yang memenuhi persyaratan. Sarannya adalah pelu adanya pengawasan dari Dinas Kesehatan Kabupaten Banyumas terhadap para pedagang es dawet yang ada di Kecamatan Sokaraja.
\end{abstract}

Kata kunci : kandungan bakteri; coliform; sanitasi tempat penjualan.

\begin{abstract}
Ice dawet is one drink with water so that the raw material is prone contaminated by microorganisms such as fungi, molds and yeasts. One relatively resistant bacteria that live in the water is coliform bacteria. Usually in sales did not pay attention to six principles of sanitation. The general objective of this study is to measure the amount of content of coliform bacteria in the ice dawet sold by each seller in the District Sokaraja 2015. Research purpose is to analyze the coliform bacteria in the ice dawet and sanitation selling ice dawet are sold in the district Sokaraja. This research is a descriptive study to gain an overview of the quality of the ice dawet seen from the content of coliform bacteria in each sample is dawet ice sold in the District Sokaraja and sanitation describe the sale of ice dawet. Results of laboratory tests on ice dawet 5 traders showed that all the samples exceeded the maximum limit of microbes that have been determined by the National Agency of Drug and Food RI No.HK 00.06.1.52.4011 regarding the determination of the maximum limit of microbial and chemical contamination is $<3 /$ ml. Concluded that the number of coliform bacteria in the ice dawet being sold on ice dawet 5 traders in District Sokaraja nothing that meet hygiene requirements. Her advice is pelu supervision of the District Health Office of Banyumas on ice dawet traders in the District Sokaraja.
\end{abstract}

Keywords : bacterial content; coliform; sanitation point of sale

\section{PENDAHULUAN}

Upaya yang dilakukan oleh bangsa Indonesia untuk meningkatkan taraf hidup penduduknya dengan pembangunan di segala bidang termasuk bidang kesehatan.Pembangunan kesehatan sebagai modal dasar pembangunan yang dirumuskan dalam Indonesia sehat 2010.Pembangunan ini mengutamakan upaya promotif dan preventif tanpa mengabaikan upaya kuratif dan rehabilitative. Dengan adanya kebijakan baru tersebut diharapkan masyarakat Indonesia akan mempunyai kesadaran, kemauan dan kemampuan untuk hidup sehat sehingga dapat terwujud derajat kesehatan yang optimal. (Depkes RI, 1999, h.4).

Hygiene sanitasi makanan dan minuman (HSMM) merupakan salah satu upaya dalam pengawasan makanan dan minuman.Melalui 6 prinsip pengelolahan makanan yang meliputi penyediaan bahan makanan, penyimpanan bahan makanan, pengolahan makanan, pengangkutan makanan, penyimpanan makanan, serta penyajian makanan dimaksudkan agar makanan dan minuman yang dihasilkan benar-benar terjangkau kualitasnya serta aman untuk dikonsumsi.

1) Email : kondang.bayu@yahoo.co.id

2) Email : dwibayukartiutami@gmail.com

3) Email : Pakzaeni@gmail.com 
Coliform merupakan suatu grup bakteri yang digunakan sebagai indicator adanya polusi kotoran dan kondisi yang tidak baik terhadap air, makanan, susu, dan produk-produk lainnya. Coliform sebagai suatu kelompok dicirikan sebagai bakteri berbentuk batang. Berdasarkan peraturan Badan Pengawas Obat dan Makanan dapat di jelaskan bahwa batas cemaran coliform adalah $<3 / \mathrm{ml}$. ( Peraturan kepala BPOM RI NO. HK.00.06.1.52.4011)

Es dawet merupakan jenus minuman dengan bahan baku yang berasal dari tepung beras, santan, larutan gula dan es. Es dawet sangat rawan terkontaminasi oleh mikroorganisme apabila dalam proses penyadiaan bahan minuman sampai penyajian minuman tidak memperhatikan hygiene sanitasi makanan dan minuman.

Sehubungan dengan hal tersebut, penulis ingin mengadakan penelitian dengan judul "Deskripsi Kandungan Bakteri Coliform Pada Es Dawet yang Dijual Di Kecamatan Sokaraja Tahun 2015”.

\section{BAHAN DAN METODE}

Jenis penelitian ini termasuk penelitian deskriptif yaitu untuk memperoleh gambarantentang kualitas es dawet dan sanitasi penjualan es dawet yang di jual di kecamatan Sokaraja.

Sampel yang digunakan dalam penelitian ini adalah 5 penjual es dawet yang berada di kecamatan Sokaraja. Kriteria tempat penjualan yang di ambil yaitu berjualan dengan cara menetap, dekat dengan sumber air, semua bahan produksi dibikin sendiri, tempat penjualan di pinggir jalan yang ramai, tempat pedagang yang laku keras penjualannya.

\section{III.HASIL DAN PEMBAHASAN}

Berdasarkan hasil perhitungan bakteri Coliform pada es dawet yang dilakukan di laboratorium Jurusan Kesehatan Lingkungan Purwokerto dari 5 sampel es dawet tidak memenuhi syarat (sampel 1 adalah $>24 / \mathrm{ml}$, sampel 2 adalah $>24 / \mathrm{ml}$, sampel 3 adalah $>24 / \mathrm{ml}$, sampel 4 adalah $>24 / \mathrm{ml}$, sampel 5 adalah 5,4/ml). Menurut Peraturan Badan Pengawas Obat dan Makanan RI No. HK.00.06.1.52.4011 tentang penetapan batas maksimal cemaran mikroba dan kimia dalam makanan.Bakteri coliform maksimum cemaran mikroba yaitu $<3 / \mathrm{ml}$.

Berdasarkan hasil tersebut upaya yang perlu dilakukan adalah diadakannya penyuluhan langsung kepada para pedagang agar dalam penyediaan bahan es dawet terutama es batu sebaiknya membuat sendiri dengan menggunakan air yang jernih dan sudah dimasak. Dalam pembuatan santan sebaiknyadimasak terlebih dahulu ,serta alat yang digunakan di cuci mengggunakan sabun kemudian dibilas dengan air yang mengalir dan pedagang mencuci tangan terlebih dahulu sebelum atau setelah bekerja.Sehinga tingkat kontaminasi dengan lingkungan dapat dikurangi.

Seorang penjamah es dawet baik dalam mempersiapkan, mengolah, menyimpan, mengangkut dan menyajikan harus memperhatikan kesehatan perorangan. Seorang penjamah makanan harus memenuhi syarat yaitu mempunyai tempramen yang baik, memiliki surat keterangan sehat, dan memiliki pengetahuan tentang hygiene sanitasi makanan dan minuman (Anwar, at, al, 1998, h.51)

Perilaku penjamah pada pedagang es dawet perlu adanya peningkatan dengan cara pemberian pamflet, atau sticker dari dinas yang bersangkutan tentang cara mencuci tangan yang baik dan akibat apabila tidak mencuci tangan.

\section{IV.KESIMPULAN}

\section{Simpulan}

Hasil penelitian bakteri Coliform yang dijual oleh 5 pedagang dikecamatan Sokaraja menunjukan hasil $\geq 3 / \mathrm{ml}$. Hasil tersebut tidak memenuhi persyaratan Peraturan Badan Pengawas Obat dan Makanan RI No. HK.00.06.1.52.4011 tentang penetapan batas maksimum untuk es dawet adalah $<3 / \mathrm{ml}$. Melihat kualitas es dawet tersebut, sebaiknya tidak layak untuk dikonsumsi, karena sudah melebihi standar yang telah ditentukan.

Berdasarkan hasil penilaian sanitasi tempat penjualan es dawet terhadap 5 panjual mendapatkan hasil rata- rata yaitu 69,11( kategori cukup ). Aspek yang dinilai antara lain perilaku penjamah,pewadahan bahan es dawet, alat yang digunakan, tempat pencucian alat, alat pembersih, tempat penjualan, tempat sampah, pengangkutan es dawet, upaya penyajian, tempat penyimpanan

\section{Saran}

Bagi peneliti menyarankan untuk peneliti selanjutnya melakukan penelitian dengan sampel yang lebih banyak

\section{DAFTAR PUSTAKA}

Anonim, Bakteri Coliform, http://putraprabu,wordpress/2008.Selasa/bakte r Coliform, diterbitkan februari 19, 2010,diakses tangggal 4 januari 2015

__ Penjual, http://id.wikipedia.org/wiki/penjual diterbitkan tanggal januari 10, 2010,diakses tanggal 4 januari 2015

Anwar, et, al,1998. Pedoman Bidang Sanitasi Makanan dan Minuman, Jakarta :Pusat Pendidikan Tenaga Kesehatan Departemen Kesehatan RI

Arif Setyo R, 2004, Studi Kandungan Bakteri Coliform pada Depot Air Minum Isi Ulang Di Kabupaten Banyumas 2004. Karya Tulis Ilmiah. Politeknik Kesehatan Semarang Jurusan Kesehatan Lingkungan Purwokerto 
Azrul Azwar, 1981, Pengantar Kesehatan Lingkungan, Jakarta : Mutiara Sumber Widya

Indonesia, Depdikbud, 1991, Kamus Besar Indonesia Edisi Kedua , Jakarta : Balai Pustaka

Indonesia, Depkes, 1989, Keputusan Dirjen POM No 03726/B/SK/VII1989 Tentang Batas Maksimum Cemaran Mikroba Dalam Makanan, Jakarta : Depkes RI

Indonesia, Depkes 1998, Permenkes RI No. $236 /$ Menkes /Per/IV/1997 Tentang Persyaratan Kesehatan Makanan Jajanan, Jakarta : Depkes RI

Keputusan Mentri Kesehatan RI, 2004, Pedoman Persyaratan Hygiene Sanitasi Makanan Jajanan, Jakarta : Depkes RI
Lasam Soeroso, 1997, Petunjuk Praktikum Mikrobiologi Lingkungan. ADKL : DepKes RI

Nurwanto, dkk.1994. Mikroba Pangan Hewani Nabati. Jogjakarta : Kamisius

Pelezar MJ dan ECS Chan, 1988 Dasar-dasar Mikrobiologi 2, Jakarta : UI Press

Srikandi Fardias, 1992, Mikrobiologi pangan, Jakarta : Gramedia Pustaka Utama

Suharsini Arikunto, 1998. Prosedur Penelitian. Jakarta : PT Rineka Cipta

Peraturan kepala BPOM RI NO. HK.00.06.1.52.4011 